\title{
Quality Assessment of Fresh Squashes through Organoleptic Analysis by Hedonic Test
}

\author{
Khushboo Gupta ${ }^{1}$, Mamta Tiwari ${ }^{2 *}$ and Gunjan Sanadya ${ }^{1}$ \\ ${ }^{1}$ KVK, Agriculture University, Kota, Rajasthan, India \\ ${ }^{2}$ Directorate of Prioritization, Monitoring and Evaluation, Agriculture University, \\ Kota, Rajasthan, India \\ *Corresponding author
}

\section{A B S T R A C T}

According to Ministry of Agriculture, Government of India the estimated production of fruits in year 2017 is 92 million tones which are more than $2 \%$ than the last year but only

Keywords

Squash,

Organoleptic

attributes,

Fresh, Fruits.

Article Info

Accepted:

04 July 2017

Available Online:

10 September 2017
$2.2 \%$ of produced fruits and vegetables were processed in food processing sector in India. In our country people prefer to consume fruits directly. Rest of the produce material destroys due to various factors. To increase the use of agro produce in processing and to reduce the waste, the present study was conducted in which fruit squashes were prepared incorporating fruit juices of lemon, pineapple, orange, amla, raw mango + ginger + mint and extracts of rose and khus. The prepared squashes were subjected to two groups and their organoleptic attributes were assessed. Nine (9) point Hedonic rating scale was used for organoleptic analysis of fresh squashes. Results revealed that various organoleptic attributes, i.e. app., colour, taste, flavour, consistency and overall acceptability of all seven squashes get $\geq 7$ hedonic scores by both groups indicating that the squashes were liked moderately to very much by them. The taste, flavour and acceptability of these squash are very good. These squashes were acceptable among both the study groups. Hence, it can be concluded that these products can be served as ready to drink products and any one can drink it and refresh himself/ herself.

\section{Introduction}

In India fruits and vegetable produced in abundant amount. They are perishable in nature and destroyes easily due to various factors. These raw food products can be stored for longer duration after changing their form and properties. Formulation of new product involves several technical aspects that supports product improvements, quality improvements, customer requests (upgradation/ acceptance) and cost saving initiatives (Vijayan and Prabhat, 2015). Numerous products, i.e., jam, jelly, squashes and beverages can be made using fruits. Fresh squashes are becoming popular compared with synthetic beverages because of refreshing quality, taste, flavor, nutritive value and storage stability of fresh squashes (Jothi et al., 2014).

Squash is quite popular all over the world as nutritious soft drinks (Babasaheb, 2000). Squash, a really to drink beverage, is nonalcoholic concentrated syrup that is usually made from fruit juice, water and sugar or 
sugar substitutes (Joseph and Shukla, 2015). It must be mixed with a certain amount of water or carbonated water before drinking. Now a day herbal extracts are added in squash to enhance its sensory and therapeutic properties (Jain et al., 2016). Lemon, orange and amla are the citrus fruits, which contain good amt of vitamin C. Lemon contains various pharmacological properties. Medicinal use of lemon is blood sugar balance, Osteoporosis, insomnia, asthma, nausea, vomiting, acne, kidney stone and sore throat (Chaturvedi et al., 2016). Pineapple is good source of vitamin B1 and B6, copper and dietary fibre. It aids in digestion and boost immunity (Hossain et al., 2015). Amla has been used in Ayurveda for treatment of several disorders, i.e. common cold, scurvy, cancer and heart disease (Jain et al., 2016). Raw Mango has refreshing taste, provides relief from dehydration and is rich source of vitamin $\mathrm{C}$ and several micronutrients. Oranges have caretenoids and flavonoids, which are cardioprotective (Jain et al., 2014). Khus has anti-inflammatory, antiseptic, Aphrodisiac, calmic and tonic effect (Balasankar et al., 2013). Therefore in present study seven different squashes were formulated incorporating fruit juices and extracts and their organoleptic attributes were assessed.

The aim of this study includes to formulate 7 different fresh squash from fruit juices and extracts. And to assess the organoleptic quality of formulated 7 squashes by group A. Also to assess the organoleptic attributes of formulated 7 squashes by group B

\section{Materials and Methods}

It was a laboratory based trial conducted within a month of preparation of particular squash during that particular season in the year 2016-2017. Different fresh squashes, i.e., Lemon, Pineapple, raw Mango + Ginger + Mint, Amla and Orange were prepared incorporating pulp of these fruits. Apart from these, Khus and Rose squashes were also prepared using extract of Khus and Rose.

\section{Formulation of squashes using fruit pulp and extracts}

Firstly juices were extracted from washed fruits using hand extractor or by machine. Then they were individually weighed by weighing balance. According to the amount of juice sugar was taken. Then sugar syrup was prepared by boiling the appropriate sugar in water and placed for cooling. The juice was mixed in cooled sugar syrup. Same procedure was followed in preparation of Khus and Rose squash.

\section{Organoleptic analysis}

According to (Reddy, 2012; Jellink, 1985) organoleptic analysis or sensory evaluation is a scientific discipline that analyses and measure human response to the composition of food or product made by the sense of taste, smell, touch and hearing when food is eaten. Two groups, i.e., group A and group B were selected for organoleptic analysis. Each group had 20 panel members thus the total sample size was 40 .

Group A was consisted with Home scientists, Horticulturists, Agronomists and Entomologists of Agriculture University, Kota. Group B was made with the common people who did not have the appropriate knowledge of different squashes. Nine point Hedonic test was used to judge the different organoleptic attributes, i.e., appearance, colour, taste, flavour, consistency and overall acceptability of the seven prepared squashes namely lemon, khus, pineapple, rose, raw mango + ginger +mint, amla and orange. In this test panel members of both groups $\mathrm{A}$ and $B$ were asked to measure the degree of pleasurable and unpleasurable experience of squashes on a nine point Hedonic rating scale 
i.e., like extremely to dislike extremely. The former carried a score of 9 while latter was scored as 1. In this scale scores were categorized as 9-Like Extremely, 8-Like Very Much, 7-Like Moderately, 6-Like Slightly, 5Neither Like nor Dislike, 4-Dislike Slightly, 3-Dislike Moderately, 2-Dislike Very Much, 1-Extremely Dislike.

Mean and standard deviation were calculated for each attribute of organoleptic analysis.

\section{Results and Discussion}

Table 1 reveals that mean hedonic scores of lemon squash were ranged between 7.7 and 8.1. colour and consistency scores were more than 7 indicating that these attributes were liked moderately by the group A, whereas rest of the attributes were marked with more than 8 hedonic score indicating that appearance, taste, flavour and overall acceptability were liked very much by these panel members. Standard deviation (SD) indicates the dispersion from mean value.

For example, higher SD value means the dispersion was high from mean. The taste, flavour and consistency of Khus squash were liked moderately by the group A as the mean scores of these attributes were more than 7 whilst appearance, colour and overall acceptability were liked very much by this group. Panel members of group A gave more than 7 scores to all attributes of pineapple squash. Taste and overall acceptability of this squash were rated liked very much by the panel members. Only colour of rose squash got hedonic score more than 8 indicating liked very much. Rest of the attributes of this squash was liked moderately by the panel members. Taste and overall acceptability of raw mango + ginger + mint squash were liked very much by the panel members whereas appearance, colour, flavour and consistency were liked moderately by them. All organoleptic attributes of amla squash got hedonic score more than 7 indicating that the squash was liked moderately by the panellists of group A. All attributes except taste and flavour of orange squash were marked by more than 7 by the group A members indicating that they liked this squash moderately. Taste and flavour was liked slightly by them. Thus the table 1 indicated that all attributes of 7 squashes were highly liked by panel members of group A.

Table 2 indicates the mean hedonic scores of organoleptic attributes rated by group B. All attributes of lemon squash got hedonic score more than 8 indicating that this squash was liked very much by all the panel members of group B. Appearance and colour of khus squash got $\geq 8$ hedonic score whereas scores of other attributes were near to the 8 indicating that the squash was liked moderately to very much.

All organoleptic attributes of pineapple squash and rose squash were higher than 8 illustrating that both squashes were liked very much by group B. The hedonic score of attributes of raw mango + ginger + mint squash ranged from 7.1 to 7.5 indicating that the products were liked moderately by the panel members of group B. Flavour and overall acceptability score of Amla squash was 7.2 and 7.5 respectively revealing that these attributes were liked moderately by the panel members. Scores of other attributes were near to 8 indicating that the likability of these attributes of Amla squash was higher than flavour and overall acceptability. Panel members gave more than 6 hedonic score to all attributes of orange squash indicating that this squash was liked slightly by the panel members of group B. 
Table.1 Mean hedonic scores of organoleptic attributes of squashes by group A

\begin{tabular}{|c|c|c|c|c|c|c|c|}
\hline Attributes & $\begin{array}{l}\text { Lemon } \\
\text { squash }\end{array}$ & $\begin{array}{l}\text { Khus } \\
\text { squash }\end{array}$ & $\begin{array}{l}\text { Pineapple } \\
\text { squash }\end{array}$ & $\begin{array}{l}\text { Rose } \\
\text { squash }\end{array}$ & $\begin{array}{l}\text { Raw } \\
\text { mango, } \\
\text { ginger } \\
\text { and mint } \\
\text { squash }\end{array}$ & $\begin{array}{l}\text { Amla } \\
\text { squash }\end{array}$ & $\begin{array}{l}\text { Orange } \\
\text { squash }\end{array}$ \\
\hline & \multicolumn{7}{|c|}{ Mean \pm SD } \\
\hline Appearance & $8.0 \pm 0.91$ & $8.5 \pm 0.51$ & $7.9 \pm 1.07$ & $7.9 \pm 0.96$ & $7.6 \pm 0.94$ & $7.6 \pm 1.14$ & $7.2 \pm 1.00$ \\
\hline Colour & $7.7 \pm 1.12$ & $8.1 \pm 0.96$ & $7.9 \pm 0.96$ & $8.1 \pm 0.71$ & $7.7 \pm 0.92$ & $7.4 \pm 0.94$ & $7.0 \pm 1.21$ \\
\hline Taste & $8.0 \pm 0.79$ & $7.6 \pm 1.04$ & $8.2 \pm 0.76$ & $7.6 \pm 1.23$ & $8.0 \pm 0.79$ & $7.1 \pm 0.30$ & $6.7 \pm 0.65$ \\
\hline Flavour & $8.0 \pm 0.91$ & $7.7 \pm 0.92$ & $7.8 \pm 1.28$ & $7.4 \pm 1.31$ & $7.8 \pm 0.76$ & $7.0 \pm 0.79$ & $6.6 \pm 1.31$ \\
\hline Consistency & $7.8 \pm 1.28$ & $7.7 \pm 0.72$ & $7.8 \pm 1.00$ & $7.5 \pm 1.05$ & $7.8 \pm 0.76$ & $7.4 \pm 0.94$ & $7.0 \pm 0.91$ \\
\hline $\begin{array}{l}\text { Overall } \\
\text { acceptability }\end{array}$ & $8.1 \pm 0.85$ & $8.0 \pm 0.64$ & $8.0 \pm 1.02$ & $7.9 \pm 0.96$ & $8.1 \pm 0.55$ & $7.1 \pm 0.94$ & $7.0 \pm 1.02$ \\
\hline
\end{tabular}

Table.2 Mean hedonic scores of organoleptic attributes of squashes by group B

\begin{tabular}{|c|c|c|c|c|c|c|c|}
\hline Attributes & $\begin{array}{l}\text { Lemon } \\
\text { squash }\end{array}$ & $\begin{array}{l}\text { Khus } \\
\text { squash }\end{array}$ & $\begin{array}{l}\text { Pineapple } \\
\text { squash }\end{array}$ & $\begin{array}{l}\text { Rose } \\
\text { squash }\end{array}$ & $\begin{array}{l}\text { Raw } \\
\text { mango, } \\
\text { ginger } \\
\text { and mint } \\
\text { squash }\end{array}$ & $\begin{array}{l}\text { Amla } \\
\text { squash }\end{array}$ & $\begin{array}{l}\text { Orange } \\
\text { squash }\end{array}$ \\
\hline & \multicolumn{7}{|c|}{ Mean \pm SD } \\
\hline Appearance & $8.5 \pm 0.51$ & $8.0 \pm 0.45$ & $8.9 \pm 0.30$ & $8.6 \pm 0.68$ & $7.2 \pm 1.00$ & $7.9 \pm 0.71$ & $6.7 \pm 1.45$ \\
\hline Colour & $8.8 \pm 0.41$ & $8.1 \pm 0.55$ & $8.7 \pm 0.47$ & $8.5 \pm 0.51$ & $7.5 \pm 0.82$ & $7.6 \pm 0.50$ & $6.3 \pm 1.12$ \\
\hline Taste & $8.5 \pm 0.51$ & $7.5 \pm 0.51$ & $8.7 \pm 0.47$ & $8.0 \pm 0.79$ & $7.1 \pm 1.07$ & $7.6 \pm 1.04$ & $6.9 \pm 0.85$ \\
\hline Flavour & $8.6 \pm 0.50$ & $7.8 \pm 0.76$ & $8.8 \pm 0.41$ & $8.3 \pm 0.80$ & $7.1 \pm 1.07$ & $7.2 \pm 0.89$ & $6.6 \pm 1.14$ \\
\hline Consistency & $8.6 \pm 0.50$ & $7.8 \pm 0.61$ & $8.6 \pm 0.50$ & $8.5 \pm 0.51$ & $7.5 \pm 1.14$ & $7.8 \pm 0.76$ & $6.8 \pm 0.89$ \\
\hline $\begin{array}{l}\text { Overall } \\
\text { acceptability }\end{array}$ & $8.4 \pm 0.50$ & $7.8 \pm 0.61$ & $8.8 \pm 0.41$ & $8.1 \pm 0.55$ & $7.3 \pm 0.92$ & $7.5 \pm 0.68$ & $6.5 \pm 1.14$ \\
\hline
\end{tabular}

Overall results indicated that squahes, like lemon squash, khus squash, pineapple squash, rose squash, raw mango + ginger + mint squash and amla squash were liked equally by the panel members of both group A and group B. These squashes were tasty and palatable. Testers said that the products were appealing, mouthwatering and had higher palatability. Panellists said that these squashes were not only had higher acceptability but they contained various therapeutic benefits also as well as they are time, money and energy saving.

Delicious squashes of fruit juices (lemon, pineapple, raw mango + ginger + mint, amla and orange) and extracts (khus and rose) were formulated in present study.

It was observed that both group A and group B liked all the squashes. On the basis of overall acceptability, it can be asserted that lemon squash, khus squash, pineapple squash, rose squash, raw mango + ginger + mint squash were liked very much by the panel members whereas amla squash and orange squash were liked moderately and slightly by them.

These can be used in our daily life due to their taste, palatability and therapeutic value along with its time, money and energy saving value. 


\section{References}

Babasaheb, B.D., Handbook of nutrition and diet. Taylor and Francis Inc, New York, United States. 2000. Pp 231-233.

Balasankar, D., Vanilarasu K, Preetha PS, Umadevi SRM, Bhowmik D. Traditional and medicinal uses of vetiver. Journal of Medicinal Plants Studies. 2013; 1(3): 191-200.

Chaturvedi, D., Shrivastava RR, Suhane N/ Basketful benefits of citrus limon. International Research Journal of Pharmacy. 2016; 7(6): 1-4.

Hossain, M.D., Akhtar S, Anwar M. Nutritional value and medicinal benefits of pineapple. International Journal of Nutrition and Food Sciences. 2015; 4(1): 84-88.

Jain, M., Singh C, Gupta K, Jain P. Optimization of functional food ingredients and their processing levels for preparation of vermicelli using
RSM. International Journal of Engineering Sciences and Research Technology. 2014;3(6):8-20.

Jain, S., Sushmita S, Mohanan A. Quality evaluation of herbal squash developed from rosemary herb and amla. International Journal of Home Science. 2016; 2(1): 210-213.

Joseph, J., Shukla S. Preparation and quality evaluation of mixed fruit squash. International Journal of Advance Industrial Engineering. 2015; 3(3): 1-5.

Jothi, J.S., Karmoker P, Sarower K. Quality assessment of mixed fruit squash: Physico-chemical analysis, sensory evaluation and storage studies. Journal of Bangladesh Agriculture University. 2014; 12(1): 195-201.

Vijayan, K., Prabhat A. Formulation, standardization and shelf life study of water melon incorporated grape squash. Current Research in Nutrition and Food Sciences. 2015; 3(2): 150-155.

\section{How to cite this article:}

Khushboo Gupta, Mamta Tiwari and Gunjan Sanadya. 2017. Quality Assessment of Fresh Squashes through Organoleptic Analysis by Hedonic Test. Int.J.Curr.Microbiol.App.Sci. 6(9): 483-487. doi: https://doi.org/10.20546/ijcmas.2017.609.058 